\title{
Temporal and Spatial Variability of Water Surplus in Ontario, Canada
}

\author{
D. Murray Brown, Humaira Dadfar, David J. Fallow, Robert J. Gordon, \\ John D. Lauzon, and Gary W. Parkin
}

School of Environmental Sciences, University of Guelph, Guelph, ON, Canada N1G 2W1

Correspondence should be addressed to Gary W. Parkin; gparkin@uoguelph.ca

Received 17 September 2013; Accepted 20 October 2013

Academic Editors: L. A. Dawson and R. N. Lerch

Copyright (C) 2013 D. Murray Brown et al. This is an open access article distributed under the Creative Commons Attribution License, which permits unrestricted use, distribution, and reproduction in any medium, provided the original work is properly cited.

\begin{abstract}
The temporal variability in estimated water surplus in 12 climatic regions of the province of Ontario, Canada, and its spatial distribution throughout most of the province are discussed in this paper. Surplus water is that which results from precipitation that runs off the land surface and that which drains through the soil profile to the water table and through subsurface drainage. A one-dimensional, deterministic model (DRAINMOD) that simulates soil water flow, including plant uptake, evapotranspiration, and freeze/thaw conditions, was used to estimate the water surplus. Simulations were performed using daily climatic data from January 1954 to December 2001 for each region. A reference corn crop and the predominant local soil conditions in each region, with the hydraulic properties for each layer in the soil profile, were used as model inputs. There was considerable year-to-year variability in annual water surplus in all regions caused by both precipitation and soil conditions. It was the least $(\sim 150 \mathrm{~mm})$ in three regions and it exceeded $350 \mathrm{~mm}$ in another three regions, where winter snowfall is the greatest as a result of these regions being in the lea of one of the Great Lakes. The variability in water surplus generally increased as average water surplus increased.
\end{abstract}

\section{Introduction}

At the end of most growing seasons in Ontario, soil water has been partially depleted from the plant root zone and deeper through evaporation from the soil surface and transpiration from plants. The growing season generally ends by midNovember in southwestern Ontario, by the end of October in the rest of southern Ontario, and by mid-October in northern Ontario as discussed in $[1,2]$. As a result, from November to March in southwestern Ontario, from November to midApril in the rest of southern Ontario, and from mid-October to April in northern Ontario, the soil water is replenished by precipitation and a water surplus occurs, as evaporation is less than precipitation. This surplus water either drains through the soil profile to the water table or through tile drainage lines (referred to collectively as deep drainage (DD)) or runs off directly into surface water (referred to as runoff (RO)), especially in the late winter and spring months as discussed in [35]. Large annual variability in soil water necessitates the use of long-term studies to adequately describe seasonal changes in water surplus as discussed in [6]. Since long-term field data are generally not available, modeling studies are necessary as discussed elsewhere [7]. The objective of this paper is to determine the variability in water surplus both temporally and spatially across Ontario from long-term modeled data using the soil hydrology model DRAINMOD. In this study, there was no attempt to verify the DRAINMOD estimates of water surplus; nevertheless, verification of DRAINMOD's satisfactory performance to simulate soil hydrology under the cold conditions of southern Canada has been performed elsewhere in $[8,9]$. As well, the emphasis of the study is on comparing estimates of water surplus between different regions of Ontario under different soil profile conditions, not on using model output to truly represent soil hydrology under a specific set of climate, crop, and soil conditions at any given location and time within each region. Nevertheless, the general hypothesis of this research is that water surplus will vary substantially between regions and from year to year. 


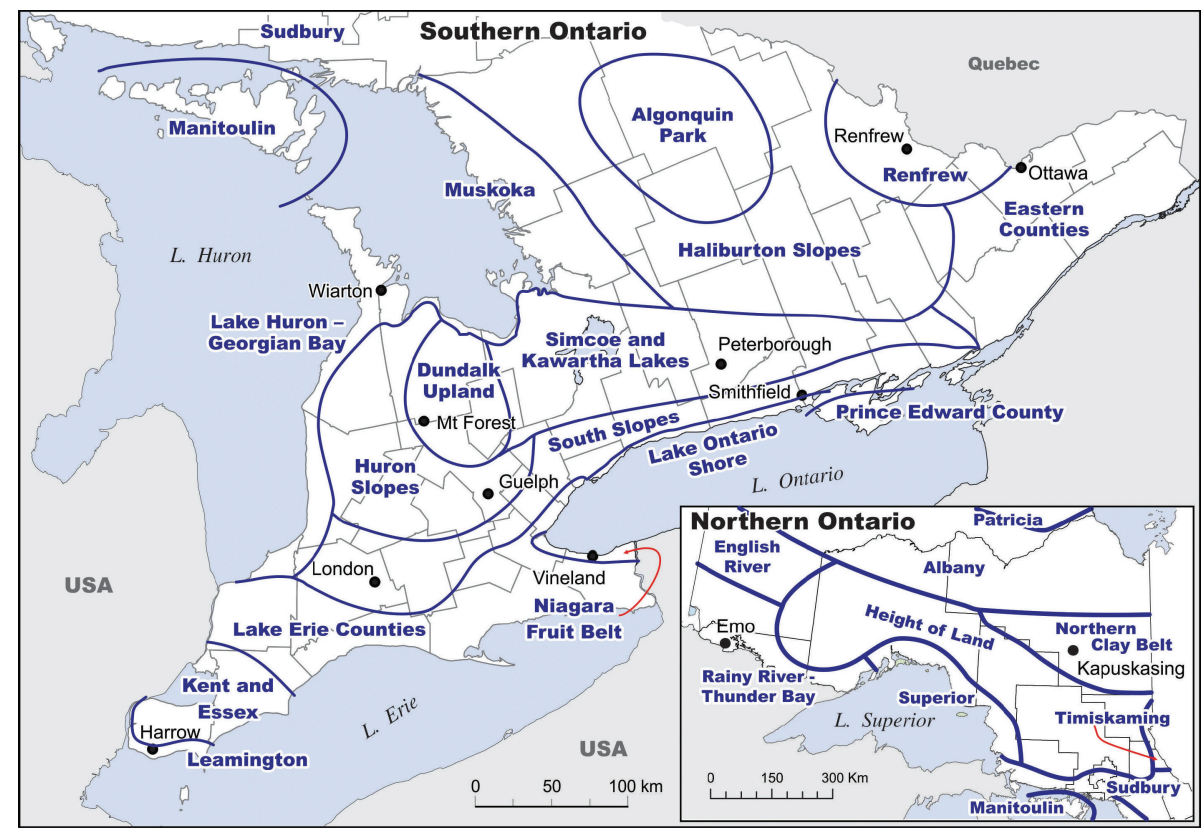

FIGURE 1: Location of the 12 stations in the climatic regions of southern and northern Ontario.

\section{Materials and Methods}

Daily climatic data (precipitation, maximum, minimum, and dew point temperatures, sunshine hours or solar radiation, and wind speed) were assembled for ten sites in southern Ontario and two sites in northern Ontario for 48 years from 1954 to 2001 (Table 1 and Figure 1). The sites were selected based on available climatic data, representing one of the climatic regions as defined in $[1,2]$. The DRAINMOD 6.0 model as discussed elsewhere $[8,10-12]$ was applied to the daily climatic data for the 48 years at all 12 sites. Table 1 gives average annual precipitation $(P)$ and estimated evapotranspiration (ET) for each site.

Precipitation was obtained from daily climatic data and ET was estimated based on the Thornthwaite (1948) approach for estimating potential evapotranspiration (PET) calibrated to long-term average estimates of actual ET based on the Penman and Monteith method as discussed in $[3,4,13]$. This approach was required because monthly calibration factors required in DRAINMOD for determining Thornthwaite's PET were not available for each site.

DRAINMOD as discussed in $[11,12]$ is a field scale deterministic hydrologic model based on the water balance technique for the soil surface and for a section of soil located midway between the adjacent drains extending from the soil surface to an impermeable layer. It estimates infiltration, ET, $\mathrm{RO}$, subsurface drainage, and seepage on an hourly or daily basis for long periods of climatic records (e.g., 50 years). Recently, it was modified to include freezing and thawing, and snowmelt components to enhance its application in cold climates as discussed elsewhere $[10,14]$. The model has been successfully tested and used under a wide variety of conditions [15-19] including climates similar to Ontario [8, 9, 20].

In terms of the lower boundary condition chosen for running DRAINMOD 6.0, no vertical or lateral seepage was allowed since the required model inputs were not available. Tile drainage was chosen to represent the lower boundary condition because it is commonly installed in Ontario and hence its required DRAINMOD inputs are well known. Therefore, DD was represented by the model estimated tile drainage. Depth and spacing of the $10 \mathrm{~cm}$ diameter tile drains were set as $100 \mathrm{~cm}$ and $15 \mathrm{~m}$, respectively, since these are average values for most subsurface drainage systems in Ontario. DRAINMOD simulations were conducted with a representative corn crop at each site over 48 years (1954-2001). Corn was chosen since it is grown throughout most of the study area and its growth parameters required to run DRAINMOD were available. Different crops were not selected according to those typically grown in each region because, as discussed above, the emphasis of this study is on comparing water surplus between regions and not crops. Corn planting dates varied slightly each year depending on springtime temperature as discussed in [21].

A local soil type, including soil horizons and their depth, that occurs in each region (Table 1, Figure 1), where the climatic site data were recorded, was used to determine water surplus (sum of RO and DD) for that site and represent the region. No attempt was made to represent soil spatial variability within a region, only between the 12 different modeled regions. In addition, DRAINMOD 6.0 was applied to clay (Oneida clay), loam (Otonabee loam), and sandy (Pontypool sand) soil profiles at all 12 sites to determine their effect on water surplus. Details on soil layers, hydraulic properties, and climate and crop inputs discussed above are given in $[3,4]$.

\section{Results and Discussion}

3.1. Temporal Variations. The low DD with clay or silty clay soils for each site resulted in the standard deviation $(s)$ of the year-to-year variability being nearly equal or greater 
TABLE 1: Average annual precipitation $(P)$, evapotranspiration $(\mathrm{ET})$, soil order, series, and textural class for local soils in each climatic region for the 12 sites.

\begin{tabular}{|c|c|c|c|c|c|}
\hline Site & Latitude & Longitude & $P(\mathrm{~mm})$ & $\mathrm{ET}(\mathrm{mm})$ & Soil order, series and texture \\
\hline Emo & $48^{\circ} 38^{\prime}$ & $93^{\circ} 48^{\prime}$ & 724 & 564 & Gleysol, Emo clay \\
\hline Guelph & $41^{\circ} 31^{\prime}$ & $80^{\circ} 14^{\prime}$ & 858 & 559 & Luvisol, Guelph loam \\
\hline Harrow & $42^{\circ} 02^{\prime}$ & $82^{\circ} 54^{\prime}$ & 881 & 730 & Gleysol, Brookston clay loam \\
\hline Kapuskasing & $49^{\circ} 24^{\prime}$ & $82^{\circ} 26^{\prime}$ & 844 & 458 & Gleysol, Ryland silty clay loam \\
\hline London & $43^{\circ} 02^{\prime}$ & $81^{\circ} 09^{\prime}$ & 942 & 690 & Luvisol, Bryanston silt loam \\
\hline Mount Forest & $43^{\circ} 59^{\prime}$ & $80^{\circ} 45^{\prime}$ & 991 & 586 & Luvisol, Listowel silt loam \\
\hline Ottawa & $45^{\circ} 23^{\prime}$ & $75^{\circ} 43^{\prime}$ & 865 & 564 & Gleysol, north Gower clay loam \\
\hline Peterborough & $44^{\circ} 14^{\prime}$ & $78^{\circ} 21^{\prime}$ & 780 & 599 & Luvisol, Otonabee loam \\
\hline Renfrew & $45^{\circ} 29^{\prime}$ & $76^{\circ} 42^{\prime}$ & 803 & 572 & Luvisol, Renfrew silty clay \\
\hline Smithfield & $44^{\circ} 05^{\prime}$ & $77^{\circ} 40^{\prime}$ & 931 & 574 & Brunisol, Pontypool sand \\
\hline Vineland & $43^{\circ} 11^{\prime}$ & $79^{\circ} 24^{\prime}$ & 836 & 711 & Luvisol, Oneida clay \\
\hline Wiarton & $44^{\circ} 45^{\prime}$ & $81^{\circ} 06^{\prime}$ & 989 & 701 & Luvisol, Harkaway silt loam \\
\hline
\end{tabular}

TABLE 2: Annual average \pm standard deviation of DRAINMOD estimated deep drainage (DD) and runoff (RO) for a local soil in each region where site is located and for a clay (Oneida clay), loam (Otonabee loam), and sandy (Pontypool sand) soil at 12 sites in Ontario.

\begin{tabular}{|c|c|c|c|c|c|c|c|c|}
\hline \multirow{3}{*}{ Site } & \multicolumn{2}{|c|}{ Local soil } & \multicolumn{2}{|c|}{ Clay soil } & \multicolumn{2}{|c|}{ Loam soil } & \multicolumn{2}{|c|}{ Sandy soil } \\
\hline & DD & RO & DD & $\mathrm{RO}$ & DD & $\mathrm{RO}$ & DD & $\mathrm{RO}$ \\
\hline & \multicolumn{8}{|c|}{$\mathrm{mm}$} \\
\hline Emo & $127 \pm 98$ & $46 \pm 44$ & $40 \pm 30$ & $139 \pm 82$ & $104 \pm 83$ & $63 \pm 52$ & $171 \pm 121$ & $27 \pm 38$ \\
\hline Guelph & $275 \pm 106$ & $25 \pm 39$ & $81 \pm 36$ & $218 \pm 80$ & $200 \pm 89$ & $89 \pm 53$ & $303 \pm 116$ & $23 \pm 35$ \\
\hline Harrow & $31 \pm 14$ & $114 \pm 59$ & $10 \pm 14$ & $68 \pm 52$ & $20 \pm 34$ & $49 \pm 48$ & $119 \pm 72$ & $34 \pm 39$ \\
\hline Kapuskasing & $154 \pm 52$ & $244 \pm 77$ & $100 \pm 37$ & $296 \pm 88$ & $246 \pm 98$ & $128 \pm 67$ & $404 \pm 120$ & $26 \pm 41$ \\
\hline London & $107 \pm 68$ & $150 \pm 77$ & $71 \pm 43$ & $198 \pm 95$ & $185 \pm 106$ & $73 \pm 68$ & $302 \pm 134$ & $19 \pm 38$ \\
\hline Mount Forest & $322 \pm 99$ & $89 \pm 69$ & $103 \pm 39$ & $297 \pm 105$ & $266 \pm 94$ & $123 \pm 77$ & $421 \pm 137$ & $12 \pm 22$ \\
\hline Ottawa & $90 \pm 40$ & $211 \pm 71$ & $64 \pm 38$ & $233 \pm 80$ & $150 \pm 91$ & $137 \pm 74$ & $269 \pm 115$ & $54 \pm 59$ \\
\hline Peterborough & $101 \pm 86$ & $90 \pm 70$ & $43 \pm 34$ & $153 \pm 82$ & $101 \pm 86$ & $90 \pm 70$ & $176 \pm 107$ & $52 \pm 53$ \\
\hline Renfrew & $18 \pm 15$ & $214 \pm 62$ & $35 \pm 28$ & $186 \pm 63$ & $113 \pm 69$ & $78 \pm 66$ & $179 \pm 100$ & $68 \pm 69$ \\
\hline Smithfield & $318 \pm 111$ & $50 \pm 55$ & $75 \pm 38$ & $262 \pm 74$ & $217 \pm 84$ & $109 \pm 60$ & $318 \pm 111$ & $50 \pm 55$ \\
\hline Vineland & $32 \pm 26$ & $101 \pm 58$ & $32 \pm 26$ & $101 \pm 58$ & $65 \pm 67$ & $54 \pm 49$ & $154 \pm 101$ & $32 \pm 36$ \\
\hline Wiarton & $130 \pm 47$ & $162 \pm 78$ & $73 \pm 27$ & $215 \pm 86$ & $186 \pm 72$ & $84 \pm 63$ & $354 \pm 107$ & $5 \pm 12$ \\
\hline
\end{tabular}

than the average annual DD (Table 2). Whereas, when sandy to loamy soils were assumed, the $s$ was near equal to or exceeded the average amount of RO. This is best illustrated at Renfrew (a region where silty clay soils are predominant) where DRAINMOD estimated DD and RO were $18 \pm 15 \mathrm{~mm}$ and $214 \pm 62 \mathrm{~mm}$, respectively (Table 2 ). Results for the clay soil at Renfrew produced DD and RO estimates of $35 \pm 28 \mathrm{~mm}$ and $186 \pm 63 \mathrm{~mm}$, respectively, and, for the sandy soil, DD and $\mathrm{RO}$ were $179 \pm 100 \mathrm{~mm}$ and $68 \pm 69 \mathrm{~mm}$. At Harrow (a region where clay loam soils (Brookston) are predominant), DD and RO were $31 \pm 14 \mathrm{~mm}$ and $114 \pm 59 \mathrm{~mm}$, respectively. At Smithfield (a region where sandy soils are predominant), $\mathrm{DD}$ and RO were $318 \pm 111 \mathrm{~mm}$ and $50 \pm 55 \mathrm{~mm}$, respectively, for the Pontypool sand. The total water surplus was over twice as much at Smithfield than at Harrow because the annual $P$ and ET were $931 \pm 107 \mathrm{~mm}$ and $574 \pm 43 \mathrm{~mm}$ at Smithfield and $881 \pm 138 \mathrm{~mm}$ and $730 \pm 102 \mathrm{~mm}$ at Harrow (Table 1).

3.2. Variability in Water Surplus. The year-to-year variability for each of the water balance components is shown in
Figures 4 to 10 in [4] for each year at 7 sites and for another 5 sites in Figures 5 to 9 in [3] and tabulated for each year in Appendix B in both of these open access publications. In this paper the number of years in which DRAINMOD estimated DD and RO exceeded specified levels at each site will be summarized. The specified levels were somewhat arbitrary, but the risk of surface and groundwater contamination, from crop production systems, would be most likely at these levels. That is, the sites with a higher frequency and greater amount of DD are seen as having a higher risk of groundwater contamination in the absence of tile drainage (i.e., nutrients, pesticides, and pathogens) as discussed in [22]. Therefore, in addition to average $\pm s$ of the water balance components derived from DRAINMOD for the local soil and a sandy soil at each of the 12 sites, the number of years in which DD exceeded 300 and $400 \mathrm{~mm}$ and the number of years in which RO exceeded 150 and $200 \mathrm{~mm}$ are summarized in Table 3. Additionally, the number of years in which annual precipitation exceeded $1000 \mathrm{~mm}$ and the years in which it was less than $800 \mathrm{~mm}$ are also provided. 
TABLE 3: Number of years that measured precipitation $(P)$ and DRAINMOD estimated deep drainage (DD) and runoff (RO) exceeded the specified limits at 12 Ontario sites for the local and sandy (Pontypool sand) soil types for the 1954 to 2001 (48 years) period.

\begin{tabular}{|c|c|c|c|c|c|c|c|c|c|c|}
\hline \multirow{3}{*}{ Site } & \multicolumn{4}{|c|}{ Deep drainage } & \multicolumn{4}{|c|}{ Runoff } & \multicolumn{2}{|c|}{ Precipitation } \\
\hline & \multicolumn{2}{|c|}{ Local soil } & \multicolumn{2}{|c|}{ Pontypool sand } & \multicolumn{2}{|c|}{ Local soil } & \multicolumn{2}{|c|}{ Pontypool sand } & \multirow[b]{2}{*}{$<800 \mathrm{~mm}$} & \multirow[b]{2}{*}{$>1000 \mathrm{~mm}$} \\
\hline & $300 \mathrm{~mm}$ & $400 \mathrm{~mm}$ & $300 \mathrm{~mm}$ & $400 \mathrm{~mm}$ & $150 \mathrm{~mm}$ & $200 \mathrm{~mm}$ & $150 \mathrm{~mm}$ & $200 \mathrm{~mm}$ & & \\
\hline Emo & 2 & 1 & 4 & 2 & 0 & 0 & 0 & 0 & 37 & 1 \\
\hline Guelph & 15 & 8 & 17 & 11 & 1 & 0 & 1 & 0 & 14 & 8 \\
\hline Harrow & 0 & 0 & 1 & 0 & 11 & 4 & 1 & 0 & 14 & 11 \\
\hline Kapuskasing & 0 & 0 & 37 & 25 & 44 & 35 & 0 & 0 & 17 & 5 \\
\hline London & 0 & 0 & 21 & 11 & 23 & 14 & 2 & 0 & 5 & 16 \\
\hline Mount Forest & 25 & 8 & 38 & 23 & 5 & 3 & 0 & 0 & 4 & 19 \\
\hline Ottawa & 0 & 0 & 19 & 6 & 39 & 24 & 2 & 2 & 15 & 7 \\
\hline Peterborough & 0 & 0 & 8 & 2 & 10 & 4 & 3 & 1 & 29 & 3 \\
\hline Renfrew & 0 & 0 & 5 & 1 & 41 & 29 & 6 & 2 & 21 & 2 \\
\hline Smithfield & 26 & 13 & 26 & 13 & 0 & 0 & 0 & 0 & 4 & 14 \\
\hline Vineland & 0 & 0 & 2 & 1 & 7 & 3 & 1 & 0 & 21 & 6 \\
\hline Wiarton & 0 & 0 & 33 & 12 & 25 & 15 & 0 & 0 & 2 & 23 \\
\hline
\end{tabular}

Estimated DD was $>300 \mathrm{~mm}$ in numerous years for the local soil profile and frequently exceeded $400 \mathrm{~mm}$ at Guelph, Mount Forest, and Smithfield. However, when the sandy soil profile was assumed in DRAINMOD at all 12 sites, DD exceeded these limits in numerous years at 7 of the 12 sites. At four of these seven sites there were more years when $P$ exceeded $1000 \mathrm{~mm}$ and fewer years when it was less than $800 \mathrm{~mm}$. The relation between DD and $P$ is illustrated in Figure 2, demonstrating the effect of texture in the soil profile on DD and how it increases with $P$. The $R^{2}$ values indicate that the positive linear relationship between $\mathrm{DD}$ and precipitation weakens as the soil texture becomes finer. As well, the $p$ value for the slope of the regression line is only significant for sand $(<0.05)$. This trend is probably related to the greater ability of clay soils to retain water than loam or sandy soils and the greater chance of runoff occurring on the clay soils. Hence, when a $P$ event occurs, drainage is more likely to happen in response to it as soil texture becomes coarser and hydraulic conductivity increases.

Analyzing the model estimates of large annual RO elucidates the high risk of surface water contamination at each site. Estimated RO exceeded $150 \mathrm{~mm}$ in more than 22 of the 48 years at five of the 12 sites for the local soil profile and for 14 or more years exceeded $200 \mathrm{~mm}$. Mean annual DD exceeded $\mathrm{RO}$ at sites where the soil profile was loamy or sandy and RO exceeded DD where the soil in the region was predominately clay or silty clay. Both climatic and soil conditions had considerable influence in determining the surplus water and the relative amounts of DD and RO. More DD than RO occurred in the summer and fall seasons, perhaps due to the relatively flat surface and daily time step used in the model runs as given in $[3,4]$. For the sandy soil profile there were very few years that RO exceeded $150 \mathrm{~mm}$, so the risk of surface water contamination is less likely in regions where sandy soils occur, but there is a greater likelihood of groundwater contamination.

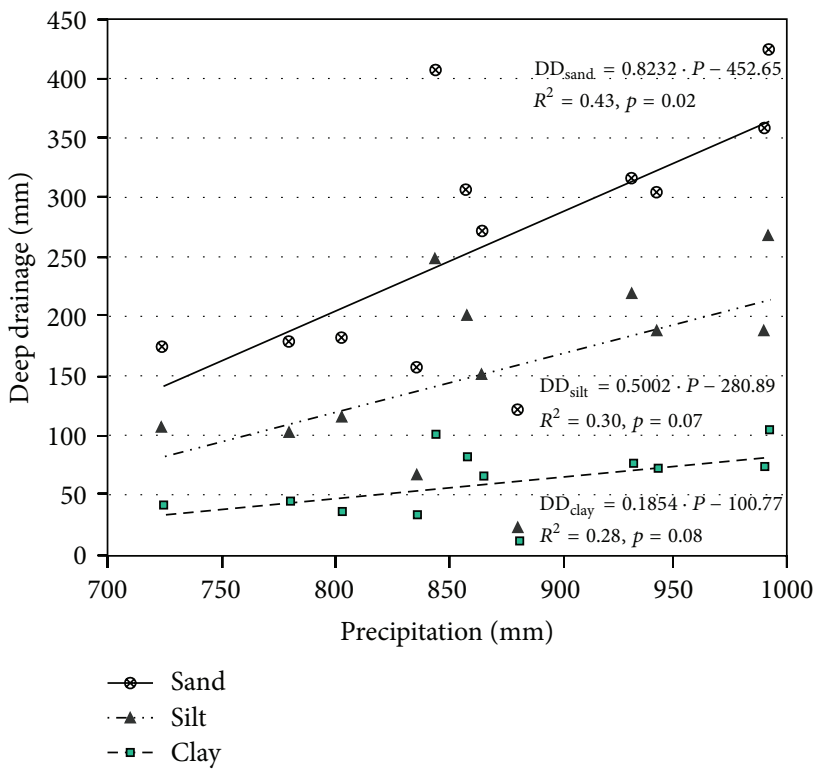

Figure 2: Comparison between average annual deep drainage $(\mathrm{mm})$ and precipitation $(\mathrm{mm})$ for the clay, loam, and sandy soil profiles used in this study at the 12 sites. $p$ indicates significance level of slope $<0.05$.

3.3. Timing of Water Surplus. As expected, the most water surplus occurred in late winter and spring seasons. For example, at Mount Forest the estimated mean water surplus in March, April, and May was 103, 169, and $46 \mathrm{~mm}$, respectively, whereas it did not exceed $30 \mathrm{~mm}$ in any other month as given in [4]. The water surplus (DD + RO) in each of the four seasons are provided in Appendix E for 7 of the 12 sites in [4] and for five sites in [3]. 


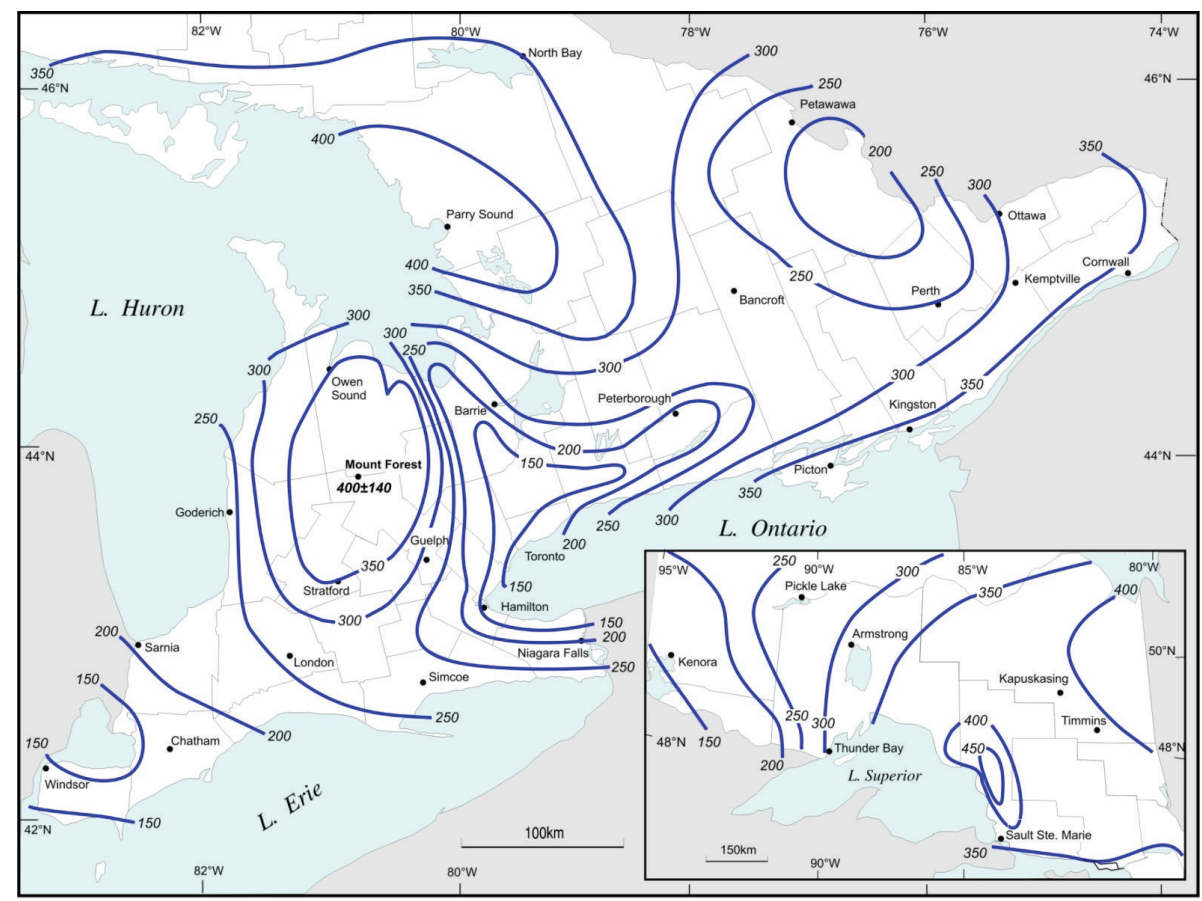

FIGURE 3: Isolines of average annual water surplus $(\mathrm{mm})$, with \pm standard deviation, $s(\mathrm{~mm})$ of water surplus shown for Mount Forest only ( $s$ for all regions given in Table 2), in southern and part of northern (inset) Ontario.

3.4. Spatial Differences in Water Surplus in Ontario. A map of average annual water surplus was created for southern Ontario and part of northern Ontario (Figure 3), using the local soil type data and previously published maps (Figure 42 in [1]; Figure 39 in [2]; and Figures 9 and 10 in [23]). Their maps were derived using the Thornthwaite approach [24], and they assumed a perennial forage crop growing season for annual water balance and the 1931 to 1960 average monthly temperature and precipitation data for over 160 climate stations.

The average annual water surplus (Figure 3 ) shows considerable differences across Ontario as discussed here using the climatic regions shown in Figure 1. It was the least $(\sim 150 \mathrm{~mm})$ in the Leamington region; in the Niagara Fruit Belt; in an area south of Barrie in the Simcoe-Kawartha Lakes and South Slopes regions; and in the Rainy River-Thunder Bay region of northwestern Ontario. Water surplus was the greatest $(\geq 350 \mathrm{~mm})$ in the Dundalk Uplands, east of Georgian Bay in the Muskoka region, and north and east of Lake Superior in the Height of Land region of northern Ontario. Mount Forest near the centre of the Dundalk Uplands region in southern Ontario averaged $405 \pm 140 \mathrm{~mm}$ and Kapuskasing in the Northern Clay Belt region averaged $389 \pm 139 \mathrm{~mm}$ over the 48-year period as given in [25] and in Appendix F in [3]. In the eastern part of southern Ontario water surplus increased gradually from $\leq 200 \mathrm{~mm}$ in the Renfrew region toward the Algonquin Park region, southeastern Haliburton Slopes region, and eastern part of the Eastern Counties region, where it exceeded $350 \mathrm{~mm}$. The variability as depicted by the $s$ generally increased as the water surplus increased.

\section{Summary and Conclusions}

The hydrologic model (DRAINMOD) that simulates soil water flow, including plant uptake, ET, and freeze/thaw conditions, was used to estimate water surplus. Simulations were performed using daily climatic data from 1954 to 2001 for 12 sites in Ontario, each one in a different climatic region. A local soil profile for each region was evaluated along with similar clay, loam, and sandy soil types including the hydraulic properties for each soil profile. The seasonal growth characteristics for a corn crop in each region were also used as input for the model. Although the corn crop was assumed in this study, the average annual water surplus for all 12 sites matched the average water surplus, estimated using the Thornthwaite method, that uses monthly climate values and assumed a perennial crop growing season, in previous studies $[1,2,23]$.

The major findings of this study were as follows.

(1) There was considerable annual variability in water surplus at all sites. The $s$ varied from 14 to $111 \mathrm{~mm}$ for $\mathrm{DD}$ and from 39 to $78 \mathrm{~mm}$ for RO for the local soil.

(2) Mean annual DD exceeded RO at sites where the local soil was loamy or sandy and RO exceeded DD where the soils were predominately clay or silty clay.

(3) Both precipitation and soil texture had a strong influence on the relative amounts of DD and RO.

(4) Estimated DD was $>300 \mathrm{~mm}$ in over half of the years at Smithfield and Mount Forest for the local soil 
profile and less frequently was $>400 \mathrm{~mm}$ at certain sites (i.e., Guelph, Mount Forest, and Smithfield).

(5) When a sandy soil was assumed for all 12 sites, DD was $>300$ and $400 \mathrm{~mm}$ in numerous years at 7 of the 12 sites. At four of the 7 sites there were more years when $P$ exceeded $1000 \mathrm{~mm}$ and fewer years when it was less than $800 \mathrm{~mm}$.

(6) Estimated RO was $>150 \mathrm{~mm}$ in $>22$ of the 48 years at 5 of the 12 sites for the local soil profile and for 14 years exceeded $200 \mathrm{~mm}$ for all sites. However, for the sandy soil profile, there were very few years that RO exceeded these limits, so the risk of surface water contamination is less likely in regions where sandy soils occur and a greater likelihood of groundwater contamination.

(7) Average annual water surplus ranged from $150 \mathrm{~mm}$ in the extreme southwest and in the Rainy River district of northwestern Ontario to over $400 \mathrm{~mm}$ at Mount Forest, Parry Sound/Muskoka district, and east of Lake Superior and was nearly $400 \mathrm{~mm}$ in the Kapuskasing/Timmins area.

The overall conclusion is that surplus water varies substantially between regions and from year to year in Ontario, which must be considered when developing policy and guidelines for source water protection.

\section{Acknowledgments}

The financial support provided by the Ontario Ministry of Agriculture and Food and Rural Affairs, Pioneer Hi-Bred Limited, Syngenta Crop Protection, and the Canadian Water Network is gratefully acknowledged. The authors' thanks are extended to Marie Puddister, Geography Department, University of Guelph for drafting the maps.

\section{References}

[1] D. M. Brown, G. A. McKay, and L. J. Chapman, "The climate of Southern Ontario," Climatological Studies 5, Department of Transport, Meteorological Branch, Toronto, Canada, 1968.

[2] L. J. Chapman and M. K. Thomas, "The climate of Northern Ontario," Climatological Studies 6, Department of Transport, Meteorological Branch, Toronto, Canada, 1968.

[3] H. Dadfar, D. J. Fallow, D. M. Brown, G. W. Parkin, J. D. Lauzon, and R. J. Gordon, "Estimation of annual and seasonal water surplus for five new regions in Ontario to identify critical regions for water quality monitoring," Technical Memo 2010-1, University of Guelph, School of Environmental Sciences, 2010, http://hdl.handle.net/10214/2231.

[4] D. J. Fallow, D. M. Brown, G. W. Parkin, J. D. Lauzon, and C. Wagner-Riddle, "Identification of critical regions for water quality monitoring with respect to seasonal and annual water surplus," Technical Memo 2003-1, University of Guelph, Department of Land Resource Science, 2003, http://hdl.handle .net/10214/2204.

[5] G. W. Parkin, C. Wagner-Riddle, D. J. Fallow, and D. M. Brown, "Estimated seasonal and annual water surplus in Ontario," Canadian Water Resources Journal, vol. 24, no. 4, pp. 277-292, 1999.
[6] R. De Jong and A. Bootsma, "Estimated long-term soil moisture variability on the Canadian prairies," Canadian Journal of Soil Science, vol. 68, no. 2, pp. 307-321, 1988.

[7] S. E. Allaire, E. van Bochove, J.-T. Denault et al., "Preferential pathways of phosphorus movement from agricultural land to water bodies in the Canadian Great Lakes basin: a predictive tool," Canadian Journal of Soil Science, vol. 91, no. 3, pp. 361374, 2011.

[8] S. Dayyani, C. A. Madramootoo, P. Enright et al., "Field evaluation of DRAINMOD 5.1 under a cold climate: simulation of daily midspan water table depths and drain outflows," Journal of the American Water Resources Association, vol. 45, no. 3, pp. 779-792, 2009.

[9] C.-C. Yang, S. O. Prasher, S. Wang et al., "Simulation of nitrate$\mathrm{N}$ movement in southern Ontario, Canada with DRAINMODN," Agricultural Water Management, vol. 87, no. 3, pp. 299-306, 2007.

[10] W. Luo, R. W. Skaggs, A. Madani, S. Cizikci, and A. Mavi, "Predicting field hydrology in cold condition with DRAINMOD," Transactions of the American Society of Agricultural Engineers, vol. 44, no. 4, pp. 825-834, 2001.

[11] R. W. Skaggs, "A water management model for shallow water table soils," Tech. Rep. 134, Water Resources Research Institute of the University of North Carolina, North Carolina State University, Raleigh, NC, USA, 1978.

[12] Soil and Water Management Group, DRAINMOD. North Carolina State University, Department of Bio and Ag Engineering, 2011, http://www.bae.ncsu.edu/soil_water/index.html.

[13] R. G. Allen, L. S. Pereira, D. Raes, and M. Smith, "Crop evapotranspiration: guidelines for computing crop requirements," FAO Irrigation and Drainage Paper 56., FAO, Rome, Italy, 1998.

[14] W. Luo, R. W. Skaggs, and G. M. Chescheir, "DRAINMOD modifications for cold conditions," Transactions of the American Society of Agricultural Engineers, vol. 43, no. 6, pp. 1569-1582, 2000.

[15] S. Ale, L. C. Bowling, J. R. Frankenberger, S. M. Brouder, and E. J. Kladivko, "Climate variability and drain spacing influence on drainage water management system operation," Vadose Zone Journal, vol. 9, no. 1, pp. 43-52, 2010.

[16] M. A. Brevé, R. W. Skaggs, J. E. Parsons, and J. W. Gilliam, "DRAINMOD-N, a nitrogen model for artificially drained soils," Transactions of the American Society of Agricultural Engineers, vol. 40, no. 4, pp. 1067-1075, 1997.

[17] M. A. Brevé, R. W. Skaggs, J. W. Gilliam et al., "Field testing of DRAINMOD-N," Transactions of the American Society of Agricultural Engineers, vol. 40, no. 4, pp. 1077-1085, 1997.

[18] G. P. Gupta, S. O. Prasher, S. T. Chieng, and I. N. Mathur, "Application of DRAINMOD under semi-arid conditions," Agricultural Water Management, vol. 24, no. 1, pp. 63-80, 1993.

[19] M. B. Shukla, S. O. Prasher, A. Madani, and G. P. Gupta, "Field validation of DRAINMOD in Atlantic Canada," Canadian Agricultural Engineering, vol. 36, no. 4, pp. 205-213, 1994.

[20] S. Wang, S. O. Prasher, R. M. Patel et al., "Fate and transport of nitrogen compounds in a cold region soil using DRAINMOD," Computers and Electronics in Agriculture, vol. 53, no. 2, pp. 113121, 2006.

[21] D. M. Brown and A. Bootsma, "Crop heat units for corn and other warm-season Crops in Ontario," Ministry of Agriculture and Food Factsheet Agdex 111/31, 1993.

[22] J. L. Hutson, "Applying one-dimensional deterministic chemical fate models on a regional scale," Geoderma, vol. 60, no. 1-4, pp. 201-212, 1993. 
[23] M. E. Sanderson and D. W. Philips, "Average annual water surplus in Canada," Climatological Studies 9, Department of Transport, Meteorological Branch, Ontario, Canada, 1967.

[24] C. W. Thornthwaite, "An approach toward a rational classification of climate," Geographical Review, vol. 38, pp. 55-94, 1948.

[25] D. M. Brown, "Average Annual Water Surplus in Ontario," 2010, https://atrium.lib.uoguelph.ca/xmlui/handle/10214/2230. 

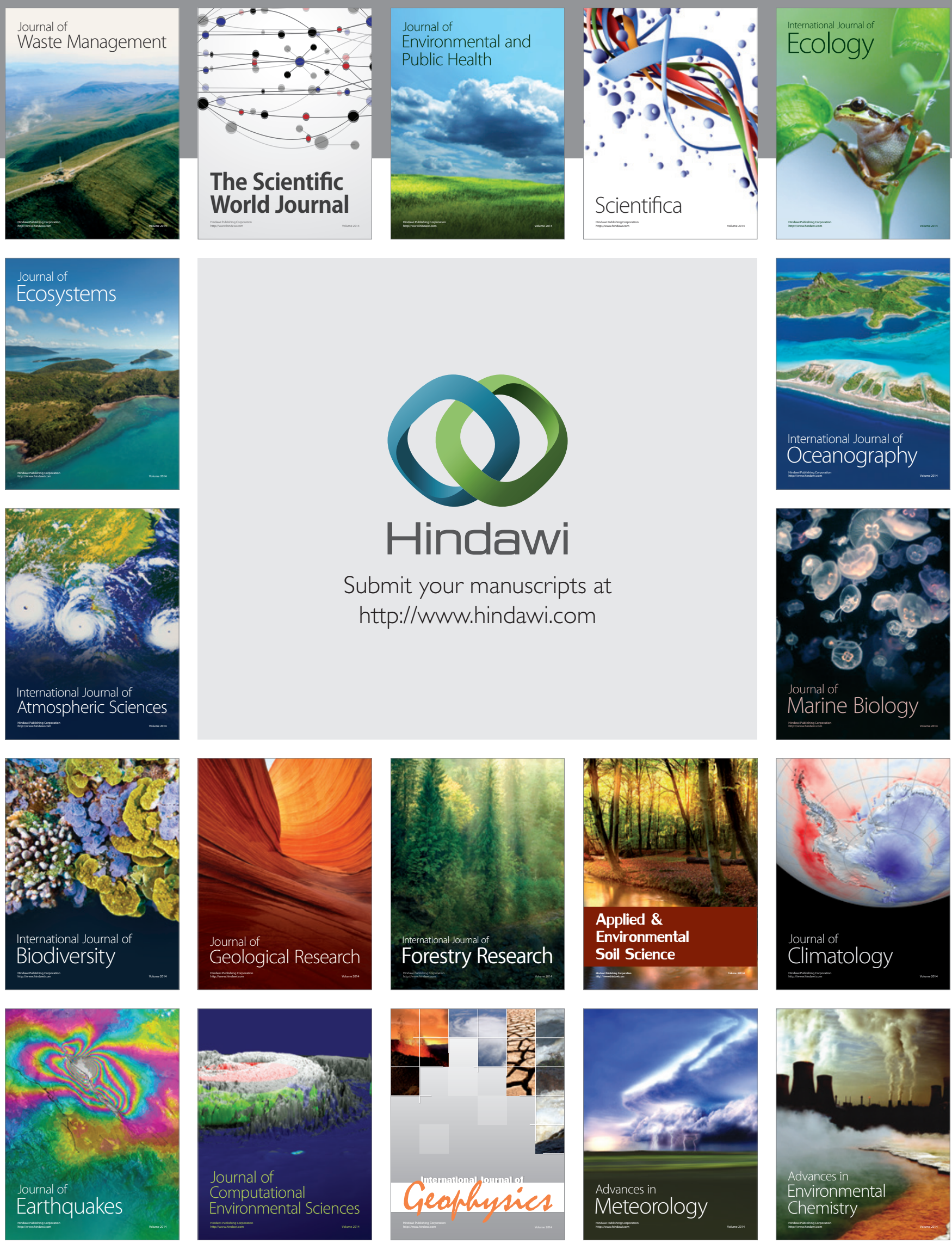